\title{
ODYSSEUS «BY ANY OTHER/BY NO NAME» CHEZ POLYPHEMOS
}

Thesis: It is an accepted fact that name-games in Heroic Age Hebrew and Greek texts (archaic loci embedded in the long-redacted Biblical and Homeric texts) held veritable significance in the period when the respective actions occurred. When in Ex. 2: 22 Moses names his First Born Son "Gēršôm», «because I was a resident-alien in a Land-Not-Mine», the implicatum is $g \bar{e} r$ šām "resident alien there» and any reader, knowing Hebrew, would recognize this second level word-game, one very serious. On the other hand, the translations of the LXX, the Vulgata, and Targum Onqelos are superb in meaning (semantically), but make the name aetiogies in vain, for they don't concern themselves with struggling to bring them across, an essential part of translation. But we are not concerned with translations in such word-games, only with the Urtext.

Nevertheless in the Urtext of Odysseia IX, the names which the protagonist gives his inhospitable host, are apparently unmotivated. The author proposes very strong double motivation for the one form, viz. Oútis, the alternate form Métis being automatically generated grammatically. As opposed to the biblical exx., knowledge of languages beyond that of the Greek Urtext is required to understand the name-games involved.

In Profound Appreciation, Impervious to Lēthē, of my Belovéd Friend,

Dr. Barbara Jean Griffith Kerns

(1918-1983),

«Dear Princess Wife» and soul-mate

of Prof. J. Alexander Kerns

(1894-1975).

Odysseus, that paradox of a being, that man who is so very much a «Somebody" that he readily and willingly divests himself of the "some» and easily becomes the «none». Every place he goes, he becomes some other life and lifestory. This is his basic mode of survival, his prime amunition of staying ahead of the «other» whom he continually comes into contact with. This Odysseus, look - in the opening of his tale by Homeros, it is first at line 21 that his name is uttered. It is in the first line that this main saving characteristic of his is highlighted 


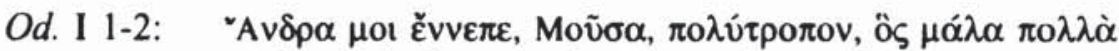

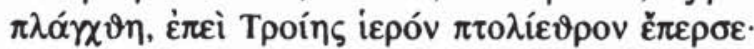

The MAN, narrate for me, $\mathrm{O}$, Musa, of-many-devices who very many [places] wandered | after Troy's Holy citadel he sacked '.

The application of this epithet in two loci where it forms part of a string of epithets is citable from the Homeric Hymn to Hermes:

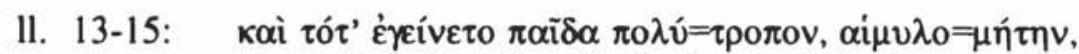

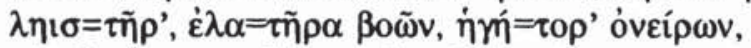

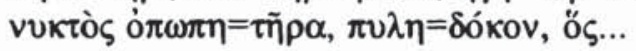

And then she bare a son of-many-devices, a contriver, a robber, a driver [off] of oxen, a bringer of dreams, a watcher, a 'receiver' -at the gates, who...

11. 436-439: Bov= $437 \pi \varepsilon v \tau \eta \dot{\kappa} \kappa o v \tau \alpha \beta$

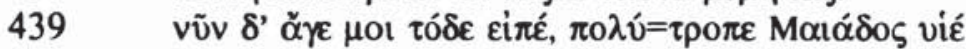

Oxen-slayer, contriver, busy-body, The Feast's Companion,

437 fifty oxen are well the equivalent worth of what you have sung.

439 But, now, come, tell me this, thou many-deviced Son of Maia.

[rendering after Evelyn-White (1914) who, however, commits the cardinal sin of Homeric type epic or hymn narration, to wit different renderings of the stock epithets in different loci: here $\pi 0 \lambda v=\tau \rho o \pi$-, rendered in the earlier locus as «(a son) of-manyshifts» ${ }^{2}$, but in the latter locus as «resourceful (son of Maia)»].

1 This epithet in the Odyssey itself reoccurs in Book X, 11. 330-331, where it is spoken by Kirke (English normally Circe, by way of Latin), after she had turned the companions into pigs:

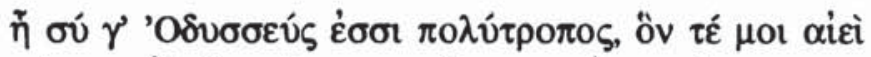

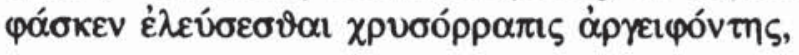

Ah, thou then Odysseus art, "of-many-devices", yea he, whom me ever kept on telling to be destined-to-come Gold-Staffed Argeiphonthes.

But in line 339 Odysseus calls Kirke's invitation «to 'mix' in bed and love that we way trust one-another». Odysseus again "calumnies» Kirke with.

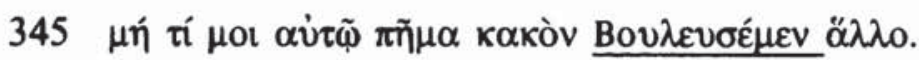

344 (Unless thou canst-dare, goddess, swear me an oath)

345 not to take counsel, to me, myself, any evil harm more.

Here "the ever self-counseling and Deviceful-One» has met his match in the formidible lady who both plans counsel-of- «deceipt» and whom Odysseus dubs also

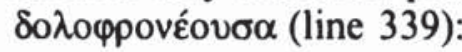

$339 \alpha$ น่tòv $\delta$ '

339 And now that you keep/hold me, myself [besides turning the companions into pigs YLA], Craft-Purposing-One, thou urgest me

340 (into the bedroom)

Certainly here neither Odysseus' $\pi 0 \lambda$ ú $\rho \circ \pi \circ \varsigma_{\text {nor }}$ the verbal forms attached by him to Kirke are formulaically innocuous.

2 "Son-of-many-Shifts" is fine, for Odysseus does very much do with verbal and mental agility that which the character of the "Supervisor of Security", Odo, does physically on Star Trek: Deep Space Nine; this Odo who is from a species «Shape-Shifters», but who 
From an etymological perspective, $\pi \mathrm{o} \lambda v=\mu \eta \tau-, \pi \mathrm{o} \lambda v-\tau \rho o \pi \mathrm{o}-$ resp. are quite literally '(man of) skill/plan/device/contrivance' and '(man of) many (twists and) turns, shifter'. The former is derived from the IE root * $m e H_{1-}$ 'to measure, to calculate, to plan'. See the intense discussion of meaning and of the many cognates in Chantraine (1974, p. 699 and, beyond this, p. 927 ibid. for the many «devious» epithets of Odysseus). The latter obviously a derivative of IE *trep- (Chantraine 1980, pp. 1132-1133) 'to turn'.

Of all these personae that Odysseus assumes facing his various hosts, that in the Kyklopeia (Cyclopeia is the usual form in English from the Latinized Greek), comprising most of Book IX, is the best known and, as the pun there unfolds, it certainly shows itself to be the preëminent amongst all in its consequences. To prepare the way for the contribution of the present paper, let us first here divest ourselves of the common opinion of what the pun consists of. This is best stated for us in Stanford $(1947, \mathrm{I}$, p. 361, 1. 408, commentary ad loc.):

The Cyclops intended to say Oriı with the recessive accent of a proper name (cp. 17, 292, "А

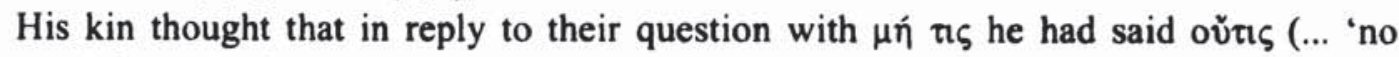
man' instead of 'No-man') as is made clear by $\mu$ ' $\pi$ c in 410 (H. elsewhere always uses ov when the indicative follows عi). The Paronomasia is further developed in $\mu \tilde{\eta} \pi \mathrm{s}$ in 414 , with a variation in 460 . There is a fuller discussion of this in my $A$ [mbiguity in] G[reek] L[iterature, Oxford, 1939], pp. 104-5.

And so, as we see, the contrived pun, in the end, saves the lives of both Odysseus and most of his men/companions. And, in this view, the name ovits which Odysseus twice gives in ll. 366 and 367 and which the Kuklop ${ }^{3}$ (sic) repeats in 1.369 , is seen as the set up/the setting of the stage for the $\mu \eta$ $\tau \iota \varsigma / M \tilde{n} \tau \iota \varsigma$ undoing pun that developes, at the very fateful moment for the Kuklop in 11. 405-410.

Now we must needs bear in mind that this dénouement of Homer's playing with Greek grammar is not a single simple pun. No, far rather does it involve at least two distinct propositions, but it seems best for the development of the matter at hand to first cite all relevant lines and only then to return to the matter of the pun's/puns' propositions. The citations are limited to three areas: 1) Odysseus' view of the Kuklops' relationships with the rest of the world, 2) his view on their relationships amongst themselves, and 3) the name matter and associated punning material (all from Book IX):

remains with never having met another who is like and who dissolves into molten matter before rematerializing.

${ }^{3}$ In my transiliterated words/names I take the liberty of dispensing with macrons. 


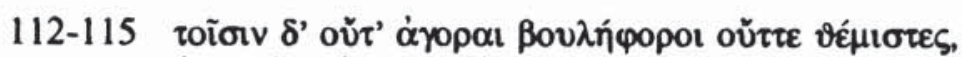

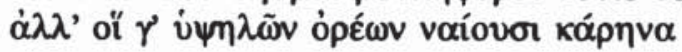

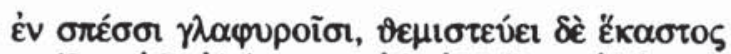

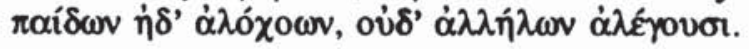

They have no counsel-bearing assemblies nor any handed-on Rights, Rather they inhabit the peaks of high mountains, in sculpted-out caves, and Each judges the Right for his children and his wives, and they have for each other no concern at all.

The "barbarity" of this most uncivilized mode of living is driven home almost violently by the triple iteration of the initial syllable of "wife, each= other, and have concern», each time /alV-/.

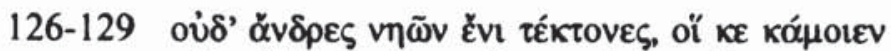

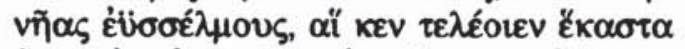

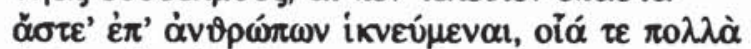

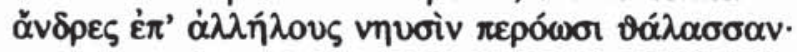

Nor amongst them are men, wrights-of-ships, who would make well-benched ships, which would effectuate their arrivals to the sundry cities of human-beings, as often men-folk traverse the Sea to each=other in ships.

Another instance of their «beyond the paleness»: they neither build the means of transportation nor do they feel the need for such - their own "society" (for what that's worth) is enough of socializing for them - no visit, no trade! The main contradiction between their behaviour and that of civilized humans lies in the word $\dot{\alpha} v \vartheta \rho \omega \tilde{\pi} \omega v$, although the less significant contradistinction is to be seen in the resp. changes between that word and the twice occurring ǒv $\delta \rho \varepsilon \varsigma$, but this a distinction that goes without saying, i. e. óv $\delta \rho \varepsilon \varsigma$ would be normal here and $\dot{\alpha} v \vartheta \rho \omega ́ \pi \omega v$ is employed only to emphasize the Kuklops' non-humankind behaviour.

146 Ěv (because of the deep mist and want of the moon)

There not any (of us) caught-sight of the Island with his (own) Eyes 4.

My emphases in that here begins the saga of «eyes and vision» which will, in due course, take us to the goal.

So much for Odysseus' instinctual feelings about the Kuklops' lifestyle in general (henceforth I will render their name into English rather than employing the Greek in transliteration: "Circle-Eye»); now we come specifically to Odysseus' reaction to and description of Polyphemos (henceforth rendered, in its

\footnotetext{
${ }^{4}$ Reading such metaphysical and modern modes of organization of the mind-body complex, such as «represents here» psychological/spiritual 'insight', more than being just anachronistic, verily boggles Homer qua Homer. We may, if so inclined, just below our consciousness, have such a sub-text program simultaneously running - but no further!
} 
few occurrences, "Many-Tale», using the type of compound which, in the grammar of Old Indic, is called a "Bahuvrihi built on a karmadhāriya»).

After an expected Greek's reactive description of the type of living quarters which Many-Tale has, Odysseus depicts the man's way of a social and isolated life:

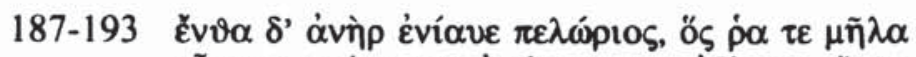

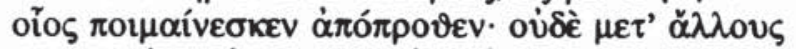

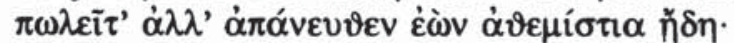

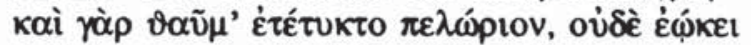

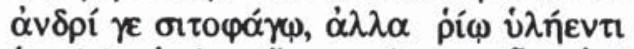

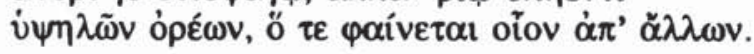

And there a man spent his nights - a monstrous (one) - note (his[own]) sheep

alone he was wont to shepherd away-in-the-distance. Nor with (any) others

(does he do his, his shepherding), but apart and separated being, he (only) knows such as is not Right to do, wrong by the Laws of Heaven's decree.

And indeed a marvel (to behold), one monstrous he had been formed (as), nor did he appear

like a bread-eating man at all, but rather (like) a wooded pinacle of high mountains, which strikes us alone from (all) the others.

Two different $\dot{\alpha} \pi$ - derived adverbs occur in this small set of verses in addition to the root, $\alpha \pi$ ó preposition itself. And there is further symmetry, three occurrences of $\dot{\alpha} \lambda \lambda$ - root likewise occur, all of them very antithetical type (cf. Autenrieth [1876] s. u.). And almost as too much of a "good thing", we get

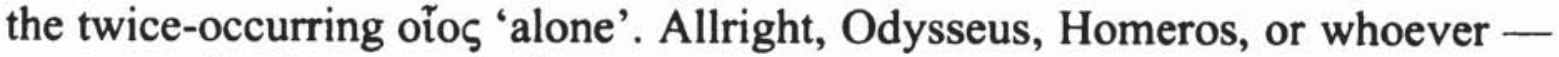
your case has been made! 5

As said above here, (1) in the view of our narrator, the Circle-Eyes ${ }^{6}$ have minimal social and civic intercourse as a whole; (2) that very minimal, even that, is eschewed by Many-Tale.

The frame within which this description of Much-Tale's hermitical life style makes for startling contrast, contrast of the same words: $172-173$ are given by

5 Many-Tale, beyond even the mere pater familias typology of the rest of the CircleEyes, is wifeless, chidless, mixes not even with a familia, from a Greek viewpoint he is really subhuman!

6 As to the rather pseudo-question as to whether "Circle-Eye» = «Single Eye», in their commentary to 1. 333, Van Leeuwen and Da Costa (ad loc., p. 205), state: «Ex hoc versu totaque quae sequitur narratione apparet poetam Polyphemum (ceterosque Cyclopes?) $\mu \mathrm{o}-$ vó $\vartheta \vartheta \alpha \mu$ ov sibi finxisse, qui inde a natalibus unum oculum haberet in media fronte collacatum, quemadmodum torvum Cyclopis vultum descripserunt Hes. Theog. 144, Theocrit. XI 31 sqq., Verg. Aen. III 636 sq., Ovid. Metam. XIII 851 sq. - Perperam Philoxenus gramaticus (cf. schol. vs. 106) contendebat posterorum hoc fuisse figmentum, Homerum

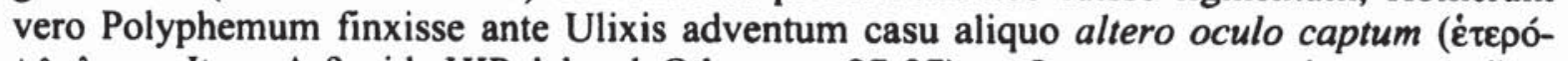
$\phi v \alpha \lambda \mu o v$. Item Ar? vid. HIPolak ad Odyss. p. 27-37) - Ipsum nomen sitne a vocibus

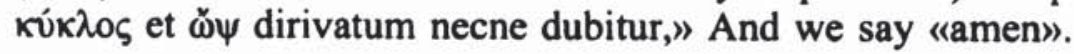


Odysseus to his men just before the $1^{\text {st }}$ set of «final instructions» before he investigates the Circle-Eyes' place (i.e. some narrative intervenes between the speech and the encounter in Many-Tale's quarters, very few lines). Lines 193195 follow Odysseus' report to his men and then he sets out again to CircleEyes' Land and, more specifically, to Much-Tale's cave:

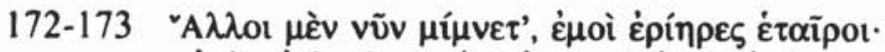

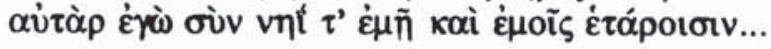

But the others. remain now, (you) to-me Loyal Companions; However I with my (own) ship, and with my (special) Fellows...

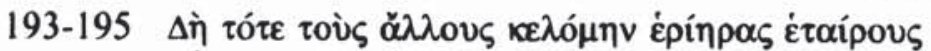
$\alpha$

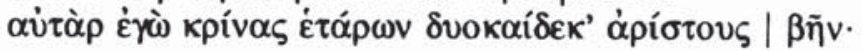

There then, the others, I bad, my loyal Companions: here, by the ship to both remain and to guard the ship.

I, however, having selected, from my companions, twelve best | to go...

We cannot not but see in these two Odyssean exhortations, that the word $\alpha 2 \lambda \lambda \circ \zeta$ is used with 'us together' sense, not with 'us vs. them' sense as it is in description of (the) Circle-Eye's/Eyes' manner of social intercourse. 172:

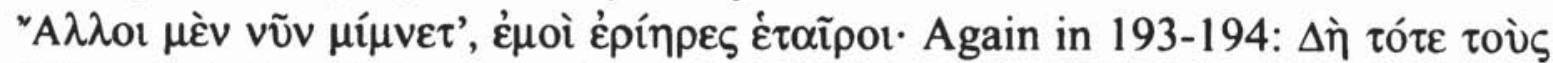

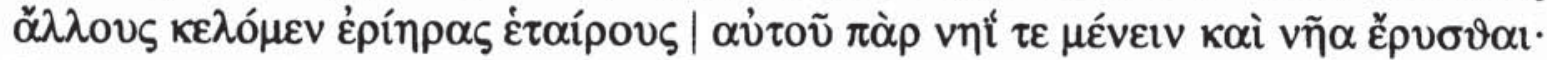
Resp. «Now then you-remain, Companions Loyal to me» and «Now then, the others I bad, Loyal Companions, | both [here] along the ship to remain and to safeguard it». Indeed the two loci primarily differ in the verb stem of «to remain». In fact these "[These] others, Loyal Companions» cannot be labelled here as "formulaic". They function as an inclusio, one that sets off in bold relief the "alien-ness» of the Circle-Eyes, against the cooperation, collaboration, fellows-of-a-single-goal of the Greeks.

Above I referred to the thricely-used «nom-de-guerre» of Odysseus, Ori $\tau \varsigma$ and stated that its use there is to be seen as the setting-up/set up for the $\mu$ ń $\tau \iota \zeta / M \tilde{n} \tau \varsigma \zeta$ «undoing pun» that will occur at $11.405-410$. We are getting there, but first we need provide the rest of the set-up.

And this «mise en scène» takes off at line 263; Many-Tale is speaking:

252-255 ...

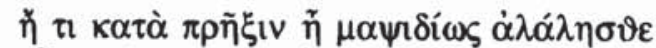

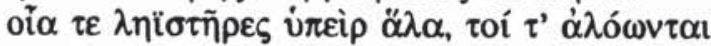

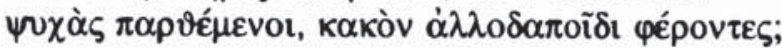

Is it for business or wantonly that you rove, as pirates upon the Sea who wander,

setting themr lives at stake, bringing Evil to Others?

Odysseus responds:

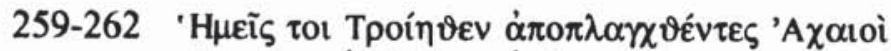

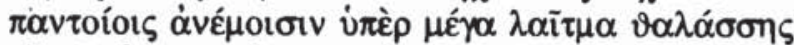

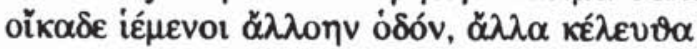




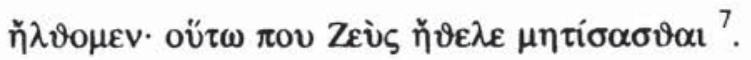

We, having-been-driven-off-course, Akhaians, by Winds coming-from-every-direction, upon the great Gulf of the Sea; making for home, 'The Other way', 'The Other Routes', did we come; Thus, for whatever reason, did Zeus devise it.

For that which the communis opinio holds to be the pun, we have started,

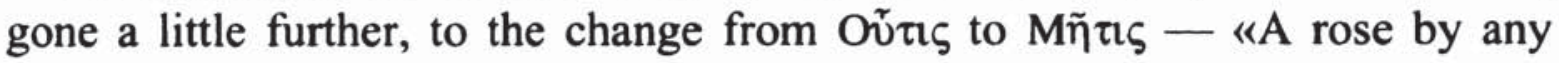
other name?» - I think not.

Notice the thricely occurring $\dot{\alpha} \lambda(\lambda)$ - in 11. 253-255, albeit that two of the three are not cognate with the "other» one. And in lines 259-262 observe well the Zeus' device causes them to be driven "Other Way" and "Other Routes», two topoi where $\dot{\alpha} \lambda \lambda$ - is the heteronym of "correct», i.e. "wrong».

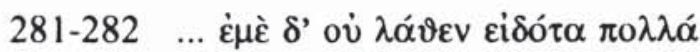

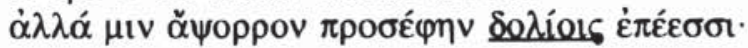

(that he was testing me) did not escape my notice, being so highly experienced.

Rather I addressed him in response with crafted words.

The consequences are disastrous, but Odysseus, ever sure of himself, a truly «some-one», a «no-one» at all,

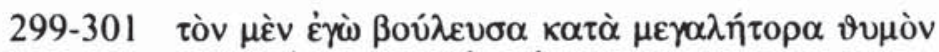

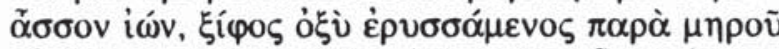

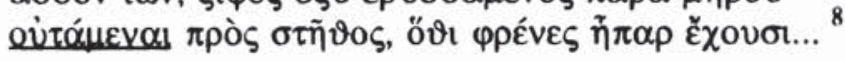

Then did I take-counsel with my spirit of profound feelings; going closer, drawing my sharp sword from my thigh's side; to wound him in the chest, where the midriff contacts the liver...

Here some good sense (from a tutelary deity?) prevails and Odysseus accepts that the fatal consequences of this act far outweigh the merit it may have seemed

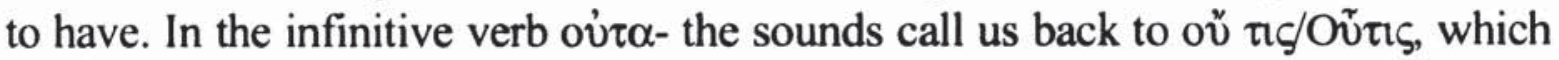
above I called a setting up for the $\mu$ í $\pi \zeta$, Mñ $\llbracket \zeta$ to come at a time where Odysseus' «Device» will serve him better than any sword could here.

Next we come to the scene where Odysseus had Many-Tale where he wants him, on the road to full inebriation, the somniferous type. The game of the name now takes place:

7 This last verb is an anticipation for what will develope in 11.377 (here, «lest any one of the companions") and the relevant to several matters here, the hendiadys in 422 (again, in context of Odysseus" "weaving Craft-and-Device» = "forming a skillfully-plotted subterfuge»).

8 Just as in the previous fn., the final infinitive here prepares or/and retrospectively glimpses, as I note in my text here; but, besides this, it also anticipates the second level "punning" in line 460 , where three sets of "puns" are in close proximaty, the two just noted and another one on «dispensing". 


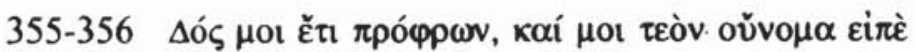

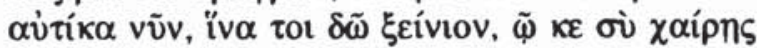

Give me more, right here and then thy name tell immediately now, so that I will be able to give thee the Host-Guest-Gift, whereby thou may(st) have pleasure.

Many-Tale requires the fulfilling of two conditions, more wine and the name of his guest. In 11. 360-363 Odysseus does readily comply with giving ManyTale the great wine thricely. Only when Many-Tale arrives at the state produced by the wine's having reached his "midriff», does Odysseus comply with the second request: the all important name.

The first of these lines, 360 , whilst of no great semantic import, is important for us to take note of, for phonetic reason, to become clear later!

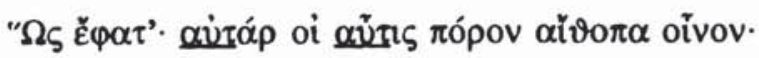

So he spoke. But to-him did I dispense again the gleaming wine.

It needs no directing of the eye or ear to feel that the bi-occurrence in the line of the bisyllabic $\alpha \dot{v}-\tau(\alpha \rho) / \alpha \tilde{v}-\tau(1 \varsigma)$ as only a further attraction of our attention.

Well, now Polyphemos has had both of his requests complied with - now the deadly word-manœvring contines in 11.364 ss.

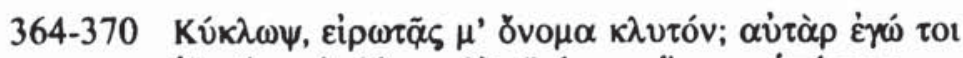

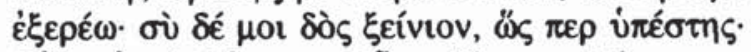

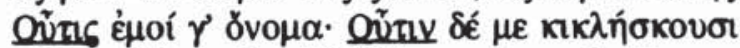

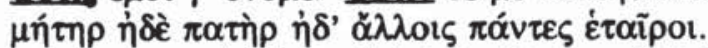

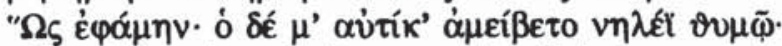

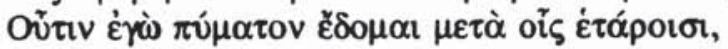

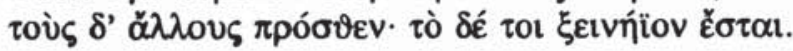

364 Circle-Eye, dost thou ask me my famed name? But, thou knowest, I too 365 have-a-request for thee: Thou, on thy part, give! me the Host-Guest-Gift, just as didst promiss.

For the present occasion I conform my translation/interpretation as the communis opinio would have it:

366 Nótany is my name; Nótany is what they call me, my Mother and my Father and the others, all my companions.

368

369

Thus I spoke; and he, at once, responded, with his pitiless spirit: Nótany I shall eat last, after his own companions,

370 and those others [«the Companions»] first; and that shall be my HostGuest Gift for you.

Before the name-game, let us notice that Polyphemos had perceived very well indeed that close «thickness» between Odysseus and his «Companions». The use of "other» ( $\left.\dot{\alpha} \lambda \lambda_{-}\right)$here is not divisive («antithetical», as opposed to «reciprocal», as they are conveniently bifurcated in the English translation of 
Autenrieth [originally 1876 in German, English tr. R. P. Keep 1958, revised by I. Flagg, p. 17]).

As for the name, I have followed tradition is retracting the accent for the proper name, while using a different lexemic constituent pair. The intention that it be a proper name is expressed in the Greek by the accusative: «l. 366 . Oõtı here becomes a proper name, 'No-man', so in the accus. it appears as

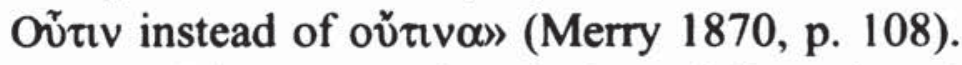

Next Odysseus pushes the bar of flame into Many-Tale's eye and we await

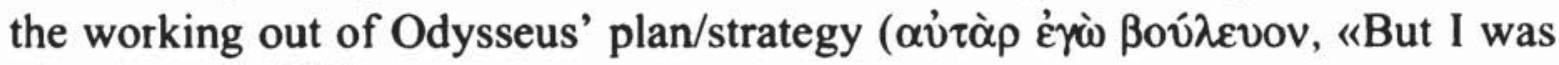
planning», 1. 420).

As a consequence of Odysseus' violence to his «(Circle)»-Eye, Many-Tales (1) screams a great scream, (2) draws out the wooden bar, now totally mixed with blood, (3) in great agony, casts-it-away - then follows what could or would be the dénouement:

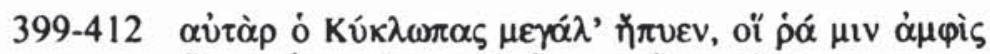

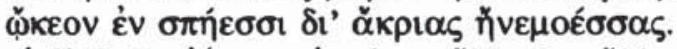

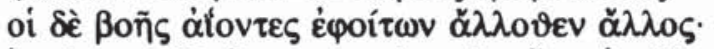

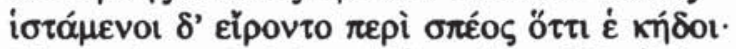

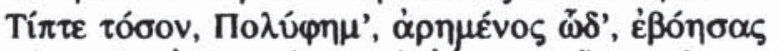

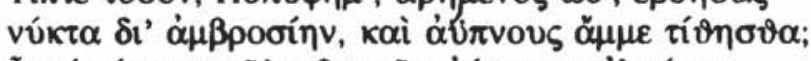

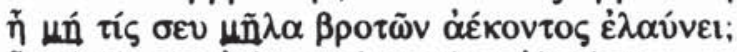

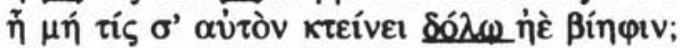

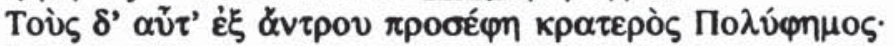

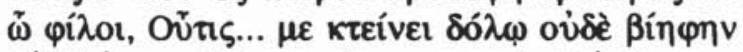

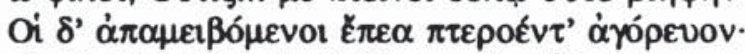

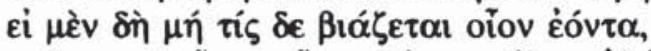

voũ $\sigma 0 v \gamma^{\prime}$ ov $\pi \omega \varsigma$ ह̌

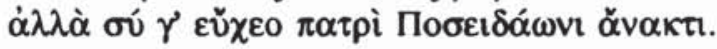

399 But he loudly hailed the Circle-Eyes who round-about him

400 dwelled in caves along the windy promontories.

401 And they, hearing the call, hurried, one from one place, another from another place.

402 So standing there, they inquired, around the cave, what it was that so vexed him;

403 What on earth, Many-Tale, are you calling so vehemently for, in the middle of immortal night, thus making us not-sleep!!??

405 So, no one drives away thy flocks, no one of mortals, against thy will? So, no one kills thee by either craft or by violence!!

407 Them answered back from his cavern the Powerful Many-Tale: $\mathrm{O}$, my friends, Nótany kills me by craft and not by violence! ${ }^{9}$

Responding with winged words, they kept offering their advice: If indeed then not-anyone violences thee, as thou art alone,

411 illness, of course, it is not possible at all, to escape it from Zeus the Great.

412 But thou then do pray to thy father, Poseidon the Lord.

\footnotetext{
9 Merry, ad loc., notes this too: «Polyphemus means, "«No-man» is [indeed YLA] slaying me by craft and not by force.' The Cyclopes understand his words, 'No man is slaying me by craft or force, and so in v. 410 ov้ $\pi \zeta$ appears $\mu \eta \dot{n} \pi \zeta$, which suggests the pun of $\mu \tilde{\eta} \pi \zeta$, inf. v. 414.» Stanford's comment ad loc., I have cited much earlier in this article.
} 
The first problematic we encounter here is that all of a sudden this colony of un-partaking of a society beings, has been transformed into a mutual aid society where these beings without council, without laws, without societal or divine norms, is now addressed by Many-Tale as «Friends, My Own!»

These beings, whom Odysseus had described as every man a pater familias to his own familia (to wit, those in his own cave!), every pater familias from each and every direction comes out to determine Many-Tale's suffering and its cause, to see if they could offer succour.

It well behooves us here to concisely as possible finish with the citations wherein the pun plays itself out:

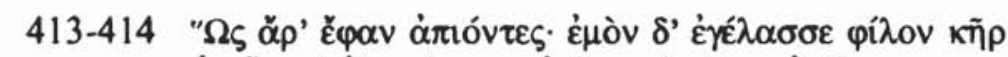

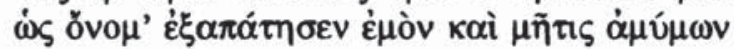

Thus did they spcak as they departed; and my own heart laughed at how the name I used had deceived and also my efficacious Device.

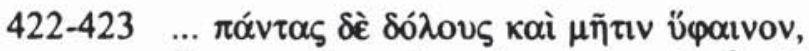

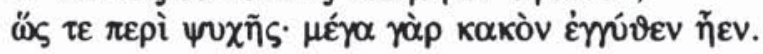

... all possible crafts and Device was I trying to weave, as in a matter of Life itself. For the Great Evil was close-at-hand.

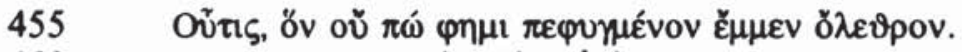

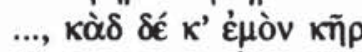

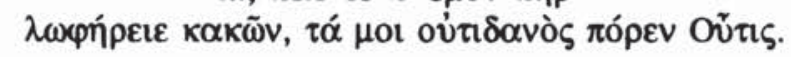

455 Nótany, whom I do not quite think to-be-fled from Destruction already. ..., which would totally relieve

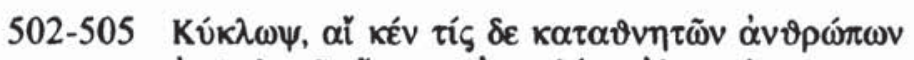

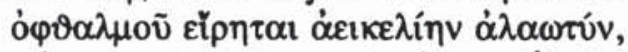

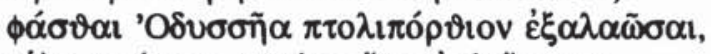

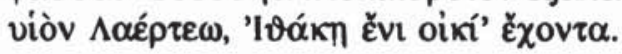

Circle-Eye, should Any of mortal-humans ask the source of the Grim Blinding of thy Eye, declare that-Odysseus, the-Sacker-of-Cities, blinded thee, Laertes'son, who keeps his home in Ithake" ${ }^{11}$.

10 The "pun» between "dispensing a burning-out of his (one and only) eye" here in 1. 460 and "dispensing more gleaming wine» in 1.360 is indeed a painful crying out by Many-Tale and man indeed, imply a retribution that would spring from the verb twice repeated. "The Evils which that Good-for-Nothing No-One/Notany dispensed to me» shows Many-Tale's own "spin», emphasizing the fullness, from beginning to end, of Odysseus' act; in 360 the text says: "But to him did I dispense again the gleaming wine", that is the inebriation, "foreplay" to the blinding, while "The many Evils" is the consequence and consumation of the dispensing act.

11 Even now, after all this interaction, Odysseus' self-expression of name and patronym and patria is hardly the Hero's «Siegmund heiss ich und Siegmund bin ich" at the end of Act I of Die Walküre, with some play on an alternate name "Friedmund", as this Hero announces himself, with Sieglinde, as husband-brother and Sword-winner. 
So, at long last, is this our result and reward?: that a member of a «folk», The Circle-Eyes, one Many-Tale by name, has now become «No-Eye(-at-all)» or «Burned-Out-Eye/Burned-out-Circle-Eye», and this by the actions of Nótany/No-One(-at-all), whose name, when wrongly accented, with an dimoric pitch on the first syllable (Mñ $\tau \varsigma$ ) rather than with a single acute on each of the two syllables in $\mu$ í $\tau i \zeta$, means «Device/Cunning" itself? Is this what the whole saga of Oỡç, beginning in line 366 , has served for - a mere triggering device (no pun intended!), first to detonate, indeed only to detonate, in the

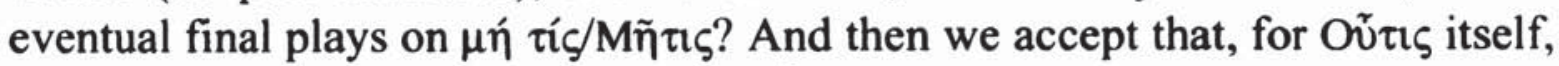
there never was any proper-to-it pun? ${ }^{12}$

Well, not bad; but I suggest we can do better and that originally «Homer» both (a) had the intention and (b) succeeded in putting in his epic, in this present pericope (whoever of the "Homers", the various adders and subtractors and redactors) of having the First pun too be more than the anemic matter we perceive it as in the Greek text! Indeed, he had this pun on Oṽ $t \varsigma$ «deliver a punch that packed a wallop» ${ }^{13}$ and what a punch it verily was.

In line 366 when Odysseus responded to Many-Tale's query about his name and then the former responded that Ovंเv/Oûtin is what his parents and the others too, all his companions call him, we see that this would-be "name» is given, by the necessity of grammar, in the accusative case. And we have noted already that this is one clue to its being, here, a proper name and not an appellative/pronominal since the latter takes a «reinforced», as it were, accusative, an original *o $\tau^{i}-v$ with $-n<\mathrm{IE} *-m$ to a vowel-stem noun/pronoun. This then was «redetermined»" ${ }^{14}$ with Greek $\alpha<{ }^{*} m_{\mathrm{o}}$ which is the outcome of the IE accusative, in Greek added to consonantal stems, thus *ou $t i-n=a$ (exactly as happens with $\mathrm{Z} \eta v / Z \eta v=\alpha$, one accusative of $Z \varepsilon v-\varsigma$ ).

Now in a declined language, all still integral Indo-European and Indo-Hittite tongues, if his parents, e. g. call him Oûtin in the accusative and in the nominative we know him as Outis, this is due to poor descriptional methodology handed on to us. If we analyze more in the way of the Sanskrit methodology,

12 A pun, totally irrelevant to Homer's usages here of that same ov้, has over the last $c$. 20 years worked itself into English academia, a «pun» that may well be less intentional that one growing out of ignorance: In American sociology courses and writings the antonym to a utopia is a dystopia, with not the east concern at all that the "u» in the Anglified roots, but word creatio ex nihilo as a whole, is from Greek ovं- (and thus «No-Place [/that does or can exist at all]») and not from Greek $\varepsilon \dot{v}$ - (and thus "Good-Place», as part of an oppositional pair: utopia:dystopia, resp. "Good-Place» [a perfect society] and "Bad-Place» [a perfectly awful society, worst you could get]).

${ }^{13}$ English idiom (/slang) for «to strike so forcefully that there may be little, if any, chance of a recovery or come back».

14 On my usage of this term, see Arbeitman \& Rendsburg (1981, p. 148 together with fn. 11). 
one that is much more in accordance with reality, the man's name (or, for that matter, any appellative) would be listed and categorized as Oṽr-; everything beyond this is mere case ending! And this is the name which The-One-of-ManyWays/Turns gave to Many-Tale, his Circle-Eye «Host»! Yet Homer never expected us to have to wait until lines much later in the pericope for the pun's resolution.

Just above I have cited Odysseus' final self-declamation - he is a real «some-one/body" this macho! Yet these lines (502-505) are the finale of what is, immediately preceding them, a two-barreled taunting for taunting's-ownsake of Many-Tale, now the Circle-Eye - even that gone, quite scorched out of its socket. These preceding lines are of two mini-episodes: in the first (475-490) Odysseus taunts the ruined Many-Tale to the point that this hurt creature takes a violent revenge. In the second (491-499) Odysseus starts to untertake a second taunting episode, only deterred by his companions who force on him the realization of the danger in giving the now BLIND-ONE vocal clues to their locations (497):

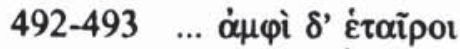

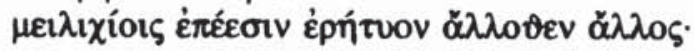

... Round-about-me, my companions tried to dissuade me with conciliatory words, one from this side, another from that side.

They did not succeed, for Odysseus had to get in, as his farewell to the Circle-Eye, Many-Tale, the previously cited 11.502 ss.: «this grim/disgusting BLINDING, tell them it was the Great I (!) who did it». This is beyond what even the gods will allow irascible Odysseus to shove into the BLIND ONE's

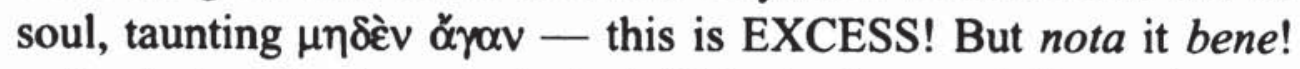

In closing, I return again to 1.366 , cited several times above already:

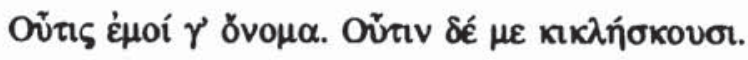

But here I will offer an original and innovative rendering in accordance with the ideas I have reflected on for the past 15 years. A rewriting of symbols first: / $a^{\hat{w}} t i-/$ emoi g' ónoma. / $a^{\hat{w}} t i-/$ dé me kikléskousi. The NAME which I here give in phonemic virgules was mis-interpreted indeed by Many-Tale the Barbarian; he understood Greek «Nótany»/«Nóbody». Odysseus, however had NOT given Greek ov tic: «Man-of-Many-Devices», such as he is, such a «nom-de-guerre» would be beneath his "greatness" and far too feeble for his level of "cruelty». Odysseus had given, as his name, the Hittite verbal form autti ${ }^{15}$.

15 For a good set of comparanda, cf. NEnglish video «television/the t. v.», from the Latin first person sg. «I see»; but we must take into consideration that the first person sg. is the citation form of any Latin verb. The appearence-wise identicaly formation audio upertaining to the broadcast, reception and reproduction of sound" and such: according to The American Heritage Dictionary of the English Language $\left(1969_{1}\right)$ and $A H D\left(1992_{3}\right)$ the noun and the 
Now what does this verbal form, used here as a personal name, mean? None other than that which is best rendered in Classical Greek as $\beta \lambda \varepsilon \varepsilon_{\varepsilon} \iota \zeta$, concerning which $L S J$, s.u. states: «see, have the power of sight (dist. fr. ó $\rho \tilde{\omega}$ 'perceive,

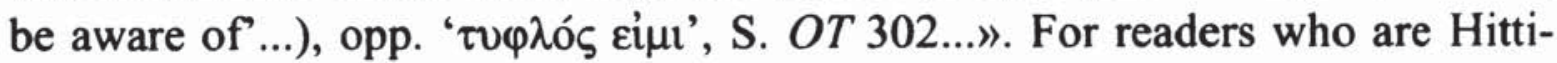
teless, let me immediately - after all your patience - translate the ad hoc Hittite "name» into the common language of the West: this Hittite $/ \mathrm{a}^{\mathrm{w}} \mathrm{ti}-/$ means 'uides' ('thou seest/du siehst', Italian 'vedi', Spanish 'ves /miras', French 'tu vois', etc.). But as both the Hittite verb autti /awti-/ and the Greek verb I rendered with, $\beta \lambda \varepsilon ́ \pi \varepsilon \varepsilon \zeta$, carry with them no baggage of the explicitly stated $2^{\text {nd }}$ p. sg. pronoun as English, German, and French do, I prefer to stick more by the renderings of the Classical Languages, viz. $\beta \lambda \varepsilon ́ \pi \varepsilon l \varsigma$ and vides resp. Also as Odysseus had spent so many years in Asian Minor Troy, there is a possibility (which I refrain from quantifying here) that he picked up some Hittite and/or Luwian there (cf. Arbeitman 1986, in toto). The oldest Germanic rendering for $\beta \lambda \varepsilon ́ \pi \varepsilon ı \zeta$ is, of course, Gothic saihuis, as we see in some of Ulfilas' rendering of the Greek.

It well behooves us first to adduce here the locus from Oidipus Tyrannos 300-303 middle. Oedipus addresses Teiresias, the Blind Seer:

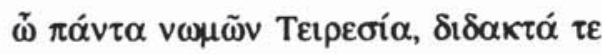

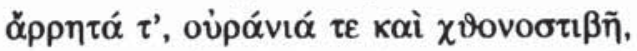

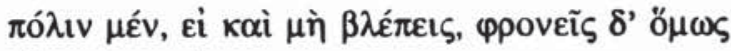

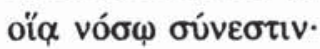

O Teiresias, The-One-Who-Grasps both matters studied and matters taboo(-to-study), matters heavenly and matters which tread this earth, This City(-of-Thebes), Even granted that thou seest not/canst not see,

Still thou knowest well the How and the Why that it is coupled with such an illness (as this plague).

The Classical Greek, and the Latin and the Gothic equivalents I have taken

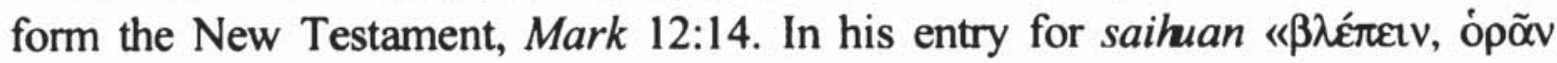
'sehen'», Feist (1939, p. 405a, s.u.), concludes: «Kein entspr. Verbum im Hett.; šak- (šag-) bed. 'wissen', ist also nicht... = got. saihuan; 'sehen' heißt hett. au-...». And so it is - the Hittite sak(iya-) being cognate with Latin sāgus et al.

Allow me to diagrammatically sketch the two aspects of the intertwining of two significant name puns which I propose we are provided with. As I see it,

adjective usages of audio are "back-formations", let us say, from a combining form audioderived from Latin verb audire. But really, one must needs remember that this dictionary goes against all tradition, by citing Latin verbs in their infinitival form, and not in their first person sg. form. Thus audio may also well be from audio (audire) resp. «I hear» («to hean)). But the time for further research, on so relatively speaking, slight a matter is not worthwhile at the present point. 
it is the Oĩ its very earliest narration - the Mĩ $\tau \zeta \varsigma$ I see as a far younger and a pun forcebly inserted to make sense of a story whose primary trigger was no longer at all understood whatsoeven in and of itself, in that latter period from the end of Hittite civilization in Asia Minor Proper, an event temporally not too separate from the end of the «Trojan War» and the destruction of the Troy of our story.

\begin{tabular}{|c|c|c|c|}
\hline & $\begin{array}{r}\text { CHAR } \\
\text { (AN ATTEMPT TO REPROD } \\
\text { OF THE PAIRS OF PU }\end{array}$ & $\begin{array}{l}\text { I } \\
\text { ICE THE } \\
\text { IS IN ENC }\end{array}$ & $\begin{array}{l}\text { SEMANTICS } \\
\text { iLISH) }\end{array}$ \\
\hline & THE PRIMARY PUN & $\begin{array}{l}\text { B. } 14 \mathrm{ss} . \\
\text {. }\end{array}$ & THE SECONDARY PUN \\
\hline A. 2 & $\begin{array}{l}\text { Odysseus, always looking forward } \\
\text { to the next problem, after plying } \\
\text { Many-Tale with the finest of wines, } \\
\text { gives his name, in response to } \\
\text { Many-Tale's offer of a host-guest } \\
\text { "Exchange», as HITTITE /a"ti-/ } \\
\text { (autti-) 'uidès'. If Many-Tale } \\
\text { was only "Semi-Barbaric» in that } \\
\text { he could only «Semi-understand» } \\
\text { Greek, his Hittite was non-existant, } \\
\text { a fact that Odysseus was playing off. } \\
\text { Many-Tale (mis-)understands what he } \\
\text { hears Odysseus give as his name, as } \\
\text { GREEK /o'ti-/ (outi-) / (ov=ti-) } \\
\text { 'Nullus/nemo', 'Not-Any (One)". }\end{array}$ & B.2. & 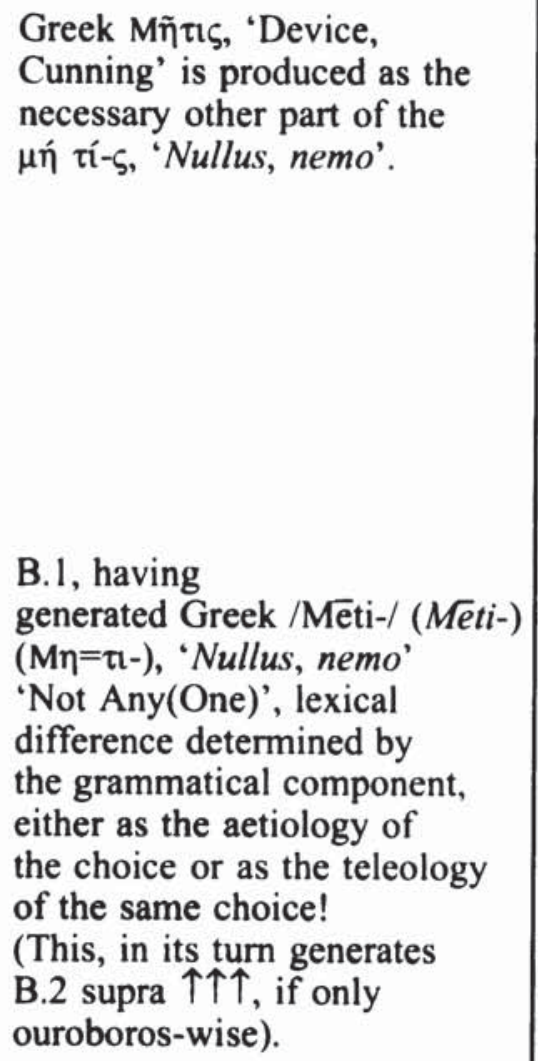 \\
\hline
\end{tabular}

But, fellow-lovers of the (ancient) word/Philologists - as alluring and satisfying to me, at least, this cruel Hittite pus is in and of itself, we have more, so much more as to constitute an embarrassment or riches.

Laroche (1959, p. 103) presents us with «ú-ut-ti-iš: 133 II 25; sg. nom.» Alas and quite self-evidentary one does not use for either (a) an etymological comparandum or (b) a textual paronomasiac elucidation (my present goals) a lexeme whose meaning is totally unsurmised («surmised» would be fraught with risk enough), let alone an item unknown beyond even the dare-heartedness to surmise! And even that which Laroche could tell us, that too eventuated 


\section{CHART II \\ (AN ATTEMPT TO REPRODUCE THE SOUNDS \\ OF THE PAIRS OF PUNS IN ENGLISH)}

A Odysseus says: «My Name is $/ \mathrm{a}^{\mathrm{w}} \mathrm{ti}-/$ (same Hittite lexeme as above):

Let's Anglify: Odysseus says: «My

Name is 'Nót-ice'. Many Tale, not understanding English, (mis-)understands this as "Not-Any(one)", present in his limited English vocabulary.

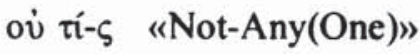

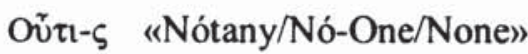

B

Odysseus says: «My Name is "No-Wight». Now although this is (1995 C.E.) "archaic» for New English, Many-Tale, again interpreting in his very limited English vocabulary, understands "Wit(s)" "16

410: $\mu \eta \dot{~} \tau i-\varsigma$ [ «(If indeed) No-Man...»] "No-Wight"

Mñ $\imath-\varsigma ~ « W i t(s) /($ wise, wis=dom»). [NE «wit», "wise, wis=dom» are syrrhizaic, of course, with the Latin uides I have been glossing The A. items with; and, obviously, with OI ved $a<* /$ woid-o $=(\mathrm{s}) /$ "Knowledge» (2. ved $a=(s), \mathrm{m}$. «Kentniss», Einsicht, Verstand», Grassmann 1872)].

to be wrong, at least in the version I adopt here. Laroche's dictionaries, his contributions to Cun. Luwian, Hiero. Luw. (his Hieroglyphic Hittite), Late Luwic Lycian, mostly today - and this is an indication of the great progress of our Fach, are from the primaeval period of our Luwiological science(s).

But for our present locus light has come. On 21/V/'93 I wrote my colleague, Prof. H. Craig Melchert (Univ. of North Carolina, USA) asking whether, in his on on-going work on his Lexica Anatolica (Cun. Luwian and Lycian, $1^{\text {st }}$ and $2^{\text {nd }}$ edd. so far all appeared), he had come to any serviceable conclusion on this «nom. sig. noun» of Laroche's without any meaning in Cun. Luw.

In his response of $24 / \mathrm{V} /{ }^{\prime} 93$, he informed me that:

There are two competing accounts. I prefer that of Morpurgo Davies, $K Z$ 94:106 ${ }^{24}$, who interprets wāsu $\bar{u} t t i s$ as 'you shall dring well' [...] Starke, Sprache 31-249f., inteprets [this form] in -tis as nom. sg. of [the noun] 'drink'. I find Morpurgo Davies' syntactic analysis with $w \bar{a} s u$ (as elsewhere) functioning as an adverb more plausible, but the context is too fragmentary to exclude Starke's interpretation entirely.

Much rich evidence do I need to exclude from Melchert's letter here and, indeed from Morpurgo Davies' (1980) fertile footnote (I discuss these ramifications in a forthcoming short article in General Linguistics). But what we get from Morpurgo Davies' analysts is a $2^{\text {nd }}$ p. sg. verb: "Thou shalt drink (well)».

16 See here fn. 18 infra. 
When we plug this date into our Odyssean pericope, we are left with little choice than to trace our protagonist's name-giving to Circle-Eyed to the creation of a wordsmith of the most archaic stratum of the Homeric corpus, for his creation and/or employment of the trilingual word-game was targeted to an audience which he could reasonably expect would catch his meanings and their references. In this sense, this audience was a step, indeed two steps, ahead of the dramatis personae, the Circle-Eyed and his fellow Circle-Eyed-Ones. But, no problem, no one would ever expect the Kuklopes to understand Greek, or either Greek, Hittite, or Luwian, far less Greek, Hittite, and Luwian. That Odysseus could cruelly pun in all three was was certainly not likely for the hearers of the Proto-Poem, but not a problem they would at all have been bothered by.

The new Luwian data, being superimposed on the Hittite punning, requires a Chart III, addendal to the recent Charts I \& II, but limited to the A column.

\author{
CHART III \\ GREEK, HITTITE, AND LUWIAN
}

«My name is»: 'No One'

Greek: Ovंt--

Hittite:/aw ${ }^{\mathrm{w}} \mathrm{i}-\mathrm{l} \quad$ 'Notice' = 'seest'

Luwian: /uti-/ 'Nog' (obsolete English for 'ale', survives only in Eggnog 'an alcoholic drink of milk, eggs with alcohol, but certainly not with ale').

$=$ 'Drink, alcoholic drink'. Alas, I cannot come up with an English verb that both (a) means 'drinkest, imbibest' and (b) sounds like 'No one, Notice' and noun 'Nog'. The Latin verb $(e-)$ bibés well serve us well. For the noun, if we go with Starke, Latin potus (its cognateness with the just given Latin verb is too opaque to matter) serves alongside

All-in-All

«My name is»: «Sum Nullus ego - nunc (bene) uidēs; sed, cum $\overline{\mathrm{e}}=$ biberis potum hunc, non uidebis umquam".

We must remember that the "giving in» by Odysseus to Circle-Eyed's importuning for his name, is surrounded by the following forms of the root * $p i-$ :

IX $346 \quad \mu \varepsilon ́ \lambda \alpha v o \varsigma$ oìvoเo.

347 Tí oĩvov,

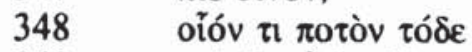

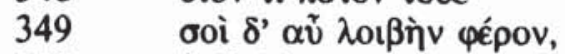

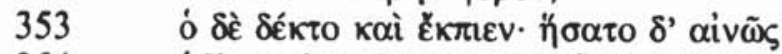

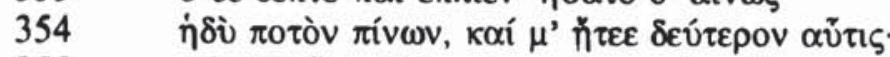

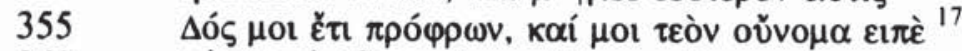

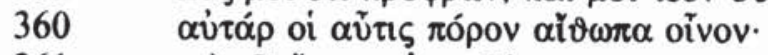

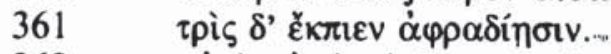

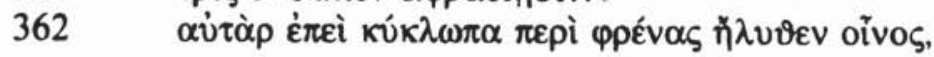

17 It will be well noted that I omit the Kuklops' tempting description of the Wine of his Land, a "tributary», if I dare, "of Ambrosia \& Nektar». 


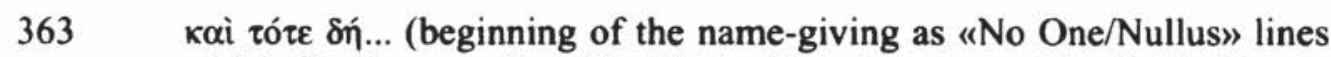
which finally come in 365 with the blatant statement itself: No One is my name; And Outis Mother and Father and all the others, the companions calle me». By three millennia earlier, this statement is "too reminiscent for comfort» by its much later, much more overblown and wild, echo in Die Walküre (end Act I): She: "Wehwalt' heißt du fürwahr?» ... He: "Siegmund heiß ich und Siegmund bin ich», etc., etc. (She: "Art thou called 'Woe-Bestower' really?..." He: "VictoryProtection' am I called and 'Victory-Protection' am I»).

While the Sister-Marrying Siegmund is an unabashed braggart, Odysseus is the supreme Cunning Man, an heroic age characteristic, as - on less grand scale - Jacob does both to his Father Isaac and to his Father-in-Law Laban.

The appropriate Greek audience for what we have herein outlined existed only at one time and one place: In Asia Minor where they dwelled symbiotically with the IE Anatolians (maybe also with more autochthonous peoples). The time was the very period within which the Trojan war took place. For when Troy falls (c. seven centuries befores the presumed 8th Cent. B.C.E. date of "The Homer», or "The Final Redactor", not counting Peisistratos nor later athetizers), the Hittite and West Luwian worlds come to an end. There were no Greeks after that who could have encapsulated in their epic significant Hittite and Luwian nomenclatural paronomasia. The Heroic Age all ended max. 1400 B.C.E. - min. 1200 B.C.E. when the Philistines invade Egypt and Canaan too.

I conclude this confrontation between Many-Tale and Odysseus with citing of lines 506-535 which I give in the standard English translation of Lattimore (1965): (Odysseus says):

506 So I spoke, and he groaned aloud and answered me, saying: "Ah now, a prophecy spoken of old is come to completion. There used to be a man here, great and strong, and a prophet, Telemos, Eurymos' son, who for prophecy was pre-eminent and grew old as a prophet among the Cyclopes. This man told me how all this that has happened now must someday be accomplished, and how I must lose the sight of my eye at the hands of Odysseus. But always I was on the lookout for a man handsome and tall, with great endowment of strength on him, to come here;

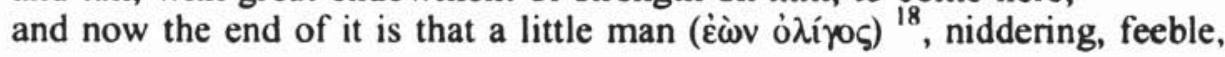

18 If one were inclined to proceed (retrograde) from the «archaic» wight to NE «obso-

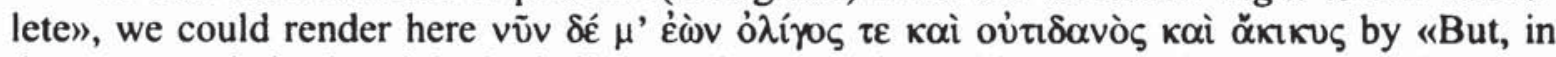
the event, a being/a wight both little and notworth-a-whit, strengthless, (| blinded) me!». Notice, but ignore, the fact that in the cazy spelling system of NE, we get the velar fricative(s) $* / w \mathrm{l} \chi \mathrm{t} /$, resp. pronounced, wight / wayt / and whit / hwIt/, with metathesis of the aspirate in, the second of the two, and consequent distinctive vowels before /-ayht/and/-It/ resp. 
has taken away the sight of my eye, first making me helpless with wihe. So come here, Odysseus, let me give you a guest-gift ${ }^{19}$ and urge the glorious Shaker of the Earth to grant you conveyance home. For I am his son, he announces himself as my father.

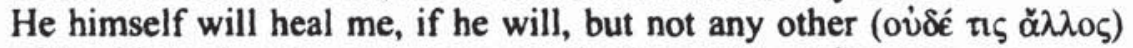

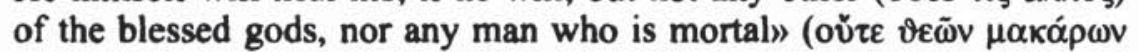

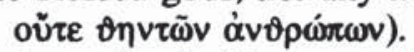

So he spoke, but I answered him again and said to him: «I only wish it were certain I could make you reft of spirit and life and send you to the house of Hades, as it is certain that not even the Shaker of the Earth will ever heal you eye for you.»

So I spoke, but he called to the lord Poseidon in prayer, reaching both his arms up toward the starry heaven: «Hear me, Poseidon who circle the earth, dark-haired. If truly I am your son, and you acknowledge yourself as my father, grant the Odysseus, Sacker of cities, son of Laertes, who makes his home in Ithaka, may never reach that home; but if it is decided that he shall see his own people ( and come home to his strong-founded house and to his own country

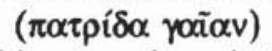

534 let his come late, in bad case, with the loss of all his companions

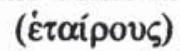

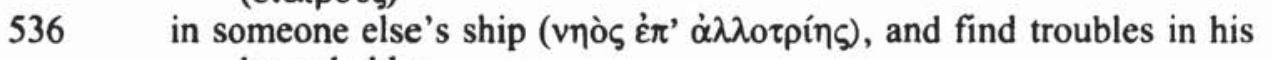
household.»

As to both Many-Tale's imprecation and also to the occasions where I inserted the Greek, res ipsae loquuntur, leaving only one single word to exege-

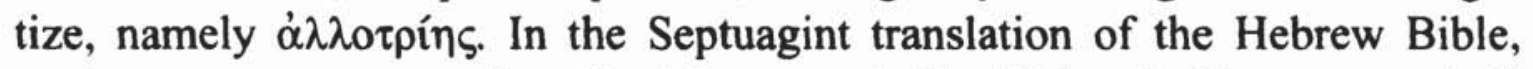
made some many centuries after Homer and all additional «Homers» and all redactors had set their text in bronze, there occurs a very, very touching and affecting usage of this same word. Exodos 2:22:

In the just made-up translation we would get a pronunciation something like:

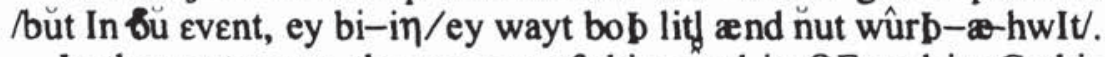

In the neuter use, the etymon of this word in $\mathrm{OE}$ and its Gothic cognate are used e. g. in Matth. 27:12: «But when he was accused by the Chief-Priests and the Elders, Gk Vorlage: où

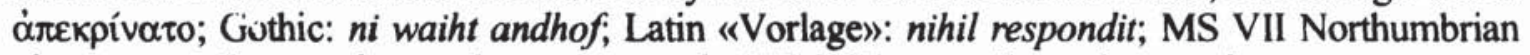
glosses: nowiht geond=uearde, geon=suarde; MS VIII: nauwiht and-swarede.

But this is $\mathrm{OE}$ gloss-language only. In the actual $\mathrm{OE}$ translations:

MS I. has: nan bing he ne and=swarode

MS V. has: nan bing he ne and-swerede (Skeat, ed., 1887), inherited with the 3 other gospels from the noble lady to whom this article is dedicated). The New Eng. derivative of this syntagm is naught (alternate spelling nought) and we can certainly translate the Greek or the Latin here as "He answered naught».

19 With reference to fn. 10 and the verses there cited with $\pi$ óp-, we take note of the parallelism of this verb with $\delta \tilde{\omega} \kappa \varepsilon$ and a case of $\pi$ ópєv having $\delta \tilde{\omega} \rho \alpha$ as its direct object! All

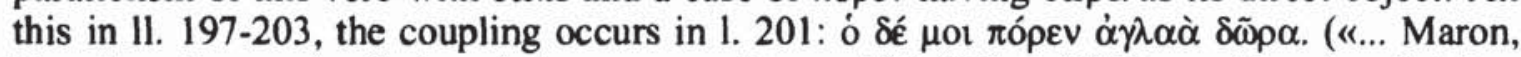
Euantheos' son, Apollo's priest, gave me it» - 197-198). |(201) « ...Yes, he distributed/presented glorious gifts.» 
Hebrew: «And Sipporah gave birth to a son and he (Moses) called him with the name Gershom (gèrrsom), for he 'explained': 'I was a metic' $(g \bar{e} r)$ in a land not my

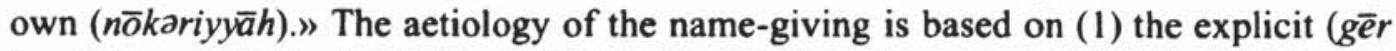
'metic') and (2) the implicit word (sam 'there'='Land not my own'). The Greek ren-

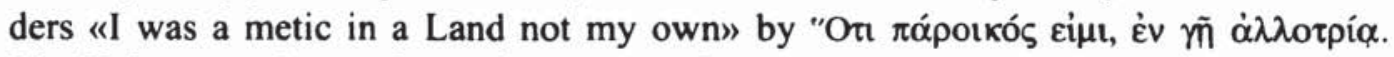
The Vulgata renders: aduena fui in terra aliena.

Odysseus knew full well in his gut that such revenge would come from Poseidon and yet he had to be finished with his close-knit group of «companions-for-the-voyage-home» (German "Gefährte» - 'travelling-mate-' — etymologically) before he could «see his own folk, those who are, by the way it is, his own men».

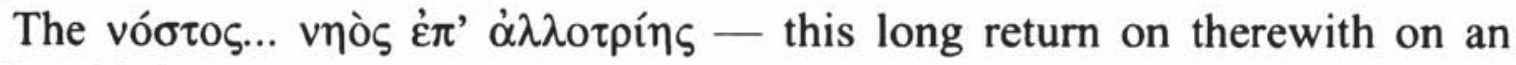
alien ship!

\section{YoËl L. ArbeitMan}

\section{REFERENCES}

Albeitman, Yoël L., 1986: “'Trojan', Luwian, and the Mass Media, 1985 (C. E.)», Diachronica III/2.

Arbeitman, Yoël L., \& Gary A. Rendsburg, 1981: «Adana Revisited [so correct wrongly printed title]: 30 Years Latern, Ar. Or. 49/2.

Autenrieth, Georg, 1876: A Homeric Dictionary (translated into English from German by Robert P. Keep; revised by Isaac Flagg; $1^{\text {st }}$ printing of new edition 1985), Norman, Oklahoma, University of Oklahoma.

Chantraine, Pierre, 1980: Dictionnaire étymologique de la langue grecque, Paris, Klincksieck.

Evelyn-White, Hugh G., 1914: Hesiod, The Homeric Hyms and Homerica, The Loeb Classical Library, Cambridge, Mass., Harvard University.

Feist, Sigmund, 1939: Vergleichendes Wörterbuch der gotischen Sprache, Dritte neubearbeitete und vermehrte Auflage, Leiden, E. J. Brill.

Grassmann, Hermann, 1872: Wörterbuch zum Rig-Veda, Leipzig, Otto Harrassowitz.

Laroche, Emmanuel, 1959: Dictionnaire de la langue louvite, Paris, Adrien Maisonneuve.

Lattimore, Richmond, 1965: The Odyssey of Homer (translated with an introduction), New York, Harper \& Row.

Melchert, H. Craig, 1993: Cuneiform Luvian Lexicon (Lexica Anatolica, volume 2), Chapel Hill, N. C., H. Craig Melchert (available from the scholar-author).

Merry, W. W., 1870: Homer: Odyssey (with introduction, notes, etc.), Oxford, The University Press.

Morpurgo-Davies, Anna, 1980: «The Personal Endings of the Hieroglyphic Luwian Verb", ZVS 94/1-2.

Skeat, Walter W. (ed.), 1887: The Gospel according to St. Matthew in Anglo-Saxon, Northumbrian, and Old Mercian Versions, Synoptically Arranged (being a revision of the incomplete 1858 edition by John M. Kemple), Cambridge, The University Press. 
Stanford, W. B., 1965: The Odyssey of Homer (edited with general and grammatical introductions, commentary, and Indexes), 2 Volumes, $2^{\text {nd }}$ Ed., London, Macmillan. Van Leeuwen, J., \& M. B. Mendes Da Costa: Homeri Odysseae Carmina (editio altera, passim aucta et emendata), ( $1^{\text {st }}$ ed. was 1890$), 2$ volumes, Lugduni Batavorum, A. W. Sijthoff. 